\title{
Is Access to Agribank Credit an Effective Tool in Improving Household Income? Evidence from the Northern Mountainous Region of Vietnam
}

\author{
Do Xuan Luan ${ }^{1,2}$, Nguyen Thanh $\mathrm{Vu}^{1,3}$, Kieu Thi Thu Huong ${ }^{1,2}$, Duong Thi Thu Hang ${ }^{3} \&$ Siegfried Bauer ${ }^{1}$ \\ ${ }^{1}$ Institute of Project and Regional Planning, Justus-Liebig-University, Germany \\ ${ }^{2}$ Faculty of economics and rural development (FERD), Thai Nguyen University of Agriculture and Forestry \\ (TUAF), Vietnam \\ ${ }^{3}$ Thai Nguyen University of Economics and Business Administration (TUEBA), Vietnam \\ Correspondence: Do Xuan Luan, Faculty of economics and rural development (FERD), Thai Nguyen University \\ of Agriculture and Forestry (TUAF), Group 10, Quyet Thang commune, Thai Nguyen city, Vietnam. Tel: \\ 84-09-8780-7896. E-mail: doxuanluan@tuaf.edu.vn; doxuanluan@gmail.com
}

\author{
Received: March 13, 2016 Accepted: April 11, 2016 Online Published: July 7, 2016 \\ doi:10.5539/ass.v12n8p110 URL: http://dx.doi.org/10.5539/ass.v12n8p110
}

\begin{abstract}
Access to credit has been thought to be a key factor in rural development and poverty reduction. In Vietnam, the Vietnam Bank for Agriculture and Rural Development (Agribank) emerged from the mono-tier banking system in 1988 and performs as a profit-oriented commercial bank sustaining the development of rural areas. During the last two decades, the bank has clearly expanded its share of credit outstanding in total rural credit market volume and this process is in line with the trending development of the national economy. The aim of this study is to examine whether Agribank credit improves household income in the Northern Mountains of Vietnam, where the poor and ethnic minorities are overrepresented in the population. In order to create robust estimates, a joint consideration of all four matching algorithms (nearest-neighbor matching, radius matching, Kernel matching and stratification matching) is applied to the Propensity Score Matching. The study found that access to extension services, ethnicity, and total savings emerged as reliable predictors of credit access among household endowments. Loan volumes increase with total value of household assets. In addition, the impact of credit lies in the range increase of $14.56 \%$ to $43.78 \%$ of total income, $12.09 \%$ to $51.83 \%$ of per capita income and $43.64 \%$ to $111.60 \%$ of nonfarm income of household with credit access. The agricultural bank credit has contributed in improving household income in the Northern Mountains of Vietnam. Results in this study provide further support for the hypothesis that the remarkable progress in poverty reduction in the last two decades in Vietnam is partly attributed to the development of Agribank credit. Experiences of the Agribank in lending to rural areas could be worthwhile for intermediary financial institutions to support rural development in Vietnam.
\end{abstract}

Keywords: Agribank, household income, northern mountains, rural credit, Vietnam

\section{Introduction}

Access to credit is believed to benefit rural households in several ways. So far, numerous studies have shown that credit helps farmers adopt new technology and improve nutritional health and education of children (Jacoby \& Skoufias, 1997; Morduch, 1999; Pitt \& Khandker, 1998). Access to production credit greatly increases household willingness to invest in higher value crops and livestock. Credit is significant for farmers to buy necessary inputs such as fertilizer, seed, crop varieties, pesticides, animal feed and so on to improve farming productivity (Zeller et al., 1998). One study by Hazarika and Alwang (2003) found that credit helps farmers shift their labor-intensive technologies to capital-intensive technology via investments in machinery and new varieties. In addition, credit can complement agricultural extension services to make farming production more efficient.

However, the role of credit in poverty reduction as well as farm development depends on specific contexts. Different countries have different pathways of developing rural credit markets. In Vietnam, after gaining independence in 1975, the economy was characterized by the central planning model, or command model, which centralized both production inputs and commodities in the form of collective ownership. Market transactions were highly regulated and extremely underdeveloped. The provision of credit to government projects, which run in the absence of incentives, led to high default rates. As a consequence, a continual decline in the production of 
rice and other commodities as well as hyperinflation led to the collapse of the economy including the credit cooperatives (Seibel, 2003). The severe food shortages, trade deficits, aid cuts and budget deficits, high inflation and a declining per capita income were all problematic for the country during that time (Van Brabant, 1990). The collapse of the whole economy in the 1980s created great pressure on policy makers in Vietnam. In response to the crisis, the government introduced a new policy called "Doi Moi" or "renovation", which opened market transactions. Households were regarded as "independent economic units" and household members could acquire loans. Also, hunger eradication and poverty alleviation were great concerns leading to the establishment of formal financial institutions like the Vietnam Bank for Agriculture and Rural Development or the Agribank (Dufhues et al., 2001).

Agriculture and rural areas play an important role in the national development of Vietnam. The agriculture sector contributes to more than $22 \%$ of Gross Domestic Product (GDP), 30\% of exports and 52\% of all employment. The agricultural growth contributed to improve household income, as around $70 \%$ of the Vietnamese population is engaged in farming activities (GSO, 2014).The Vietnamese government has paid considerable attention to rural poverty reduction. It has adopted for this purpose a number of credit schemes because rural households see capital shortage as the greatest constraint to expand production and improve their livelihood. As a result, rural credit in general and Agribank credit in particular expanded remarkably since the establishment of the bank (Figure 1). The Agribank is a good illustration of the transformation from the mono-tier banking system to a system of banks operating on the basis of market principles in 1988 (Seibel, 1992). Central to the establishment of the Agribank are the market principles to reduce subsidized directed credit programs in rural areas. The bank is a successful case in providing financial services to a majority of rural inhabitants as well as supporting rural development projects such as rural infrastructural development.

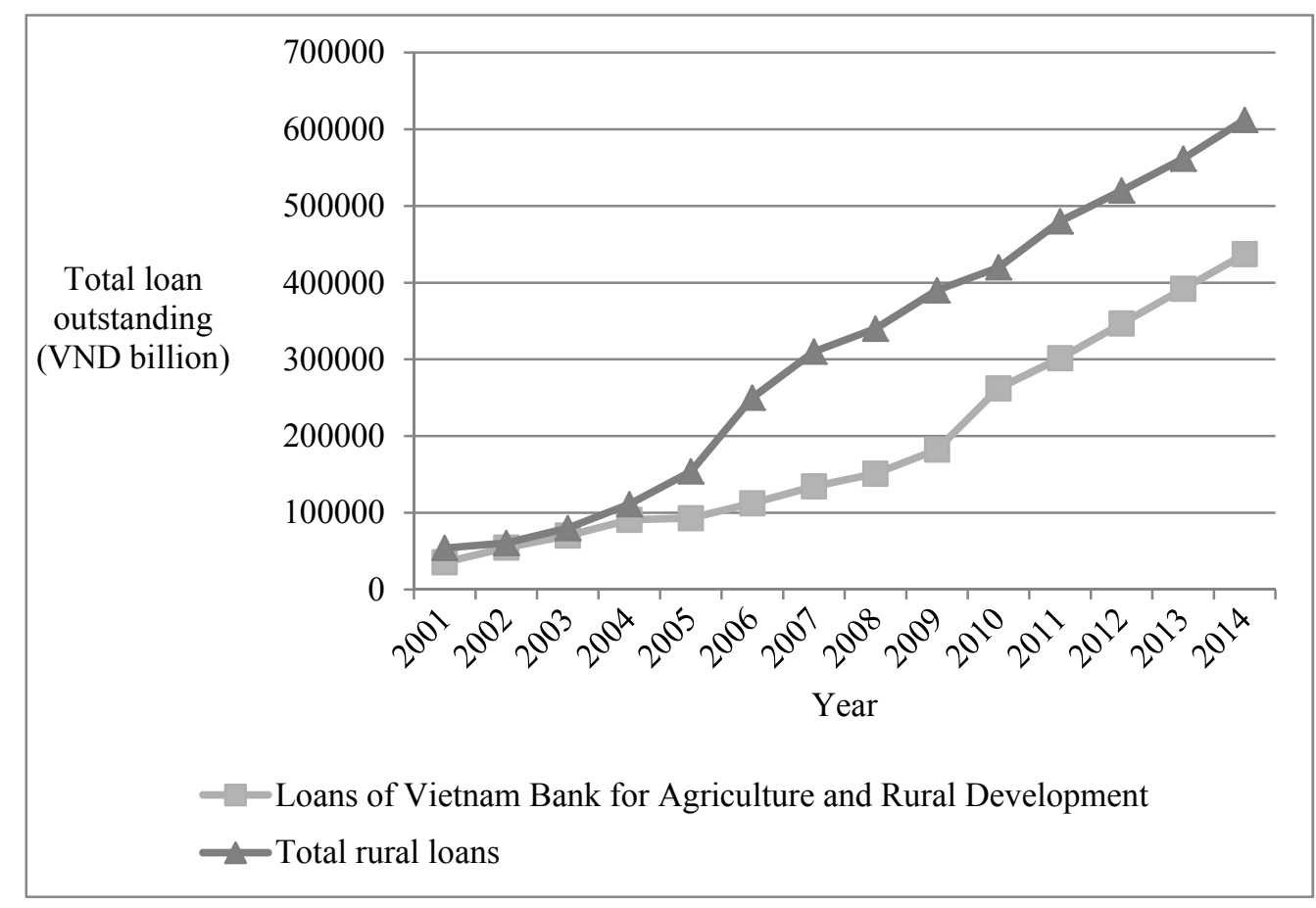

Figure 1. Expansion of rural credit in Vietnam for the period 2001-2014

Source: Own calculation based on Vietnam's General Statistics Office and annual reports of Agribank for the period 2001-2014

The Agribank is the leading bank in Vietnam in terms of fund resources, assets and loan outstanding disbursed to rural areas. It has made up a high market share of rural credit market in Vietnam (Figure 2). Currently, the Agribank is the leading credit provider in the rural credit market of Vietnam. In 2008, 45\% of its deposits were mobilized from the city and 55\% from the savings from rural areas. By the end of 2014, the Agribank made up $70 \%$ of credit market share in terms of total loan outstanding in rural Vietnam. It has provided a full range of services including both credit and savings to total 10 million households, of which 4.7 million are low-income 
households which have per capita monthly income of around 1 VND million or around $\$ 50$ (GSO, 2014). Funds mobilized from the population represented $60.60 \%$ of capital structure and the bank has covered $45.29 \%$ of total rural households with formal savings in Vietnam (Agribank, 2014). The outstanding loans to agriculture, farmers and rural areas reached VND 437265 billion (around \$15 billion), a 26\% increase compared to 2012, accounting for nearly $70 \%$ of the Agribank's total loan portfolio.

The expansion of the Agribank credit to rural areas could be one of the factors explaining the remarkable achievement in poverty reduction during the last two decades in Vietnam. The poverty headcount rate has reduced from nearly $60 \%$ of the population in 1993 to $8.4 \%$ in 2014 (GSO, 2014). The main objectives of this study are to identify which household endowments influence access to Agribank credit and to know whether the provision of said credit improves household income in disadvantaged rural areas of the country. If the Agribank is an effective tool in improving household income, then looking at its experiences in rural credit development is worthwhile.

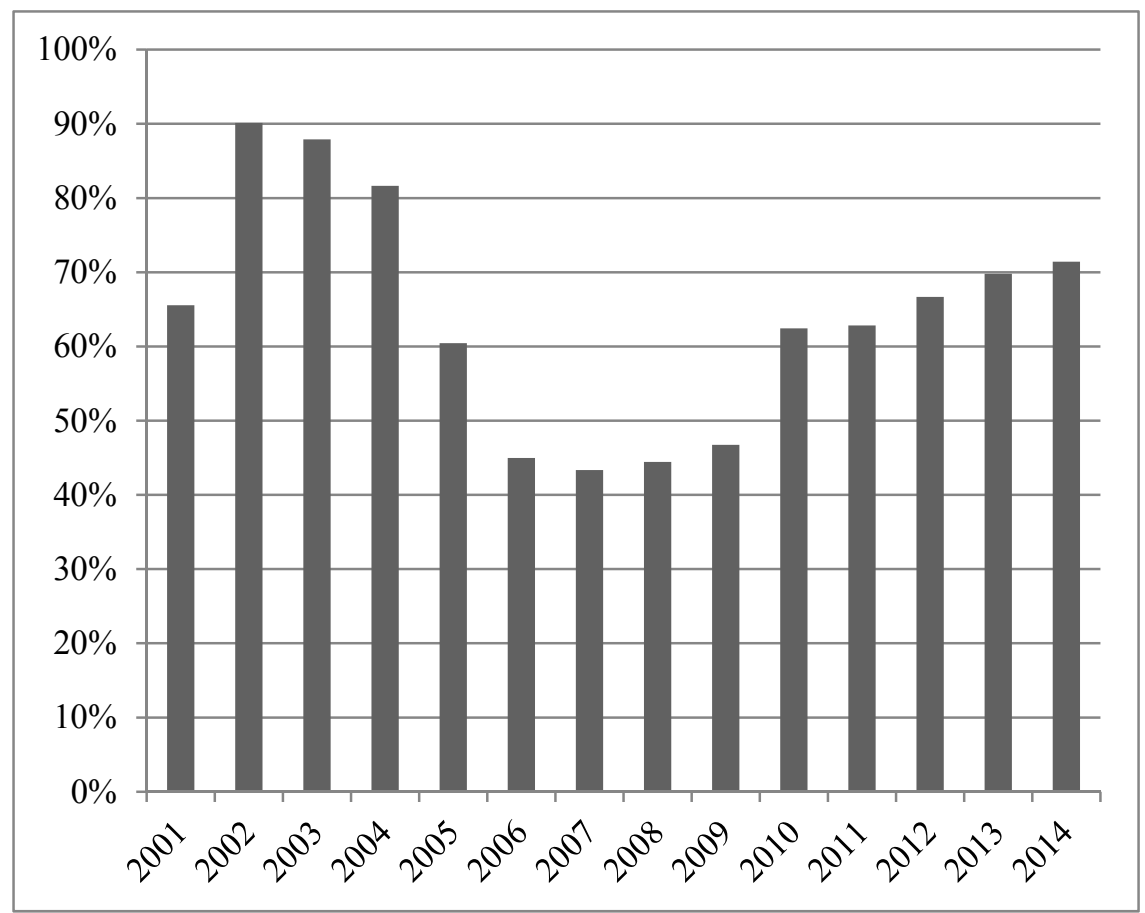

Figure 2. Market share of the Agribank credit in total rural credit market in Vietnam (\% of total rural loan outstanding)

Source: Own calculation based on the Vietnam's General Statistics Office and annual reports of the Agribank for the period 2001-2014

\section{Data and Method}

\subsection{Data}

This study uses observational data drawn from the 2012 round of the Vietnam Access Resources Household Survey (VARHS). The survey aims at exploring the living conditions of rural households, especially the poor and ethnic minorities in Vietnam. The survey was jointly conducted by three Vietnamese organizations including the Institute for Policy and Strategy for rural development (ISPARD), the Central Institute for Economic Management (CIEM) and the Institute for Labour Science and Social Affairs (ILSSA). It covers a total of 3700 sampled households in 12 provinces and all relevant costs of the survey were financed by the Organization of the Danish International Development Assistance (DANIDA). The sampling techniques and data cleaning were supported by the Department of Economics at the University of Copenhagen.

This study uses data of 1338 households from four provinces including Lai Cai, Phu Tho (North East), Lai Chau and Dien Bien (North West) in the Northern Mountains of Vietnam. The region is comparably less developed than other regions of Vietnam. The region, comprising of 15 provinces, is the second largest area in Vietnam. It 
makes up nearly $29 \%$ of the total national area and is characterized by a high proportion of rural residents (see Table 1 for further details). Another characteristic of the region is that there is a higher number of ethnic minorities compared to other regions of the country. In 2012, the Vietnamese population was around 87.84 million people, of which ethnic minorities accounted for about $14.5 \%$ (GSO, 2012) and the remaining $85.50 \%$ were the Kinh majority population. Around fifty percent of Vietnam's minorities live in the Northern Mountains and most of them remain rural residents (World Bank, 2009). Ethnic minorities include Tay, Nung, Dao, and H'Mong, among other groups. In the total population in the region, the Kinh majority people account for $66.1 \%$, Tay ethnic people represent 12.4\%, Nung 7.3\%, Dao 4.5\%, and H'Mong 3.8\% (GSO, 2012). Poverty, low agricultural productivity, and land degradation remain major problems for the minority community.

Table 1. Socio-economic indicators of the Northern Mountains in relation to other regions and the whole country in 2014

\begin{tabular}{|c|c|c|c|c|c|}
\hline Indicators & $\begin{array}{l}\text { The } \\
\text { Northern } \\
\text { Mountains }\end{array}$ & $\begin{array}{l}\text { Whole } \\
\text { country }\end{array}$ & $\begin{array}{c}\text { Rank in } 6 \\
\text { regions of } \\
\text { Vietnam (1: } \\
\text { highest; 6: } \\
\text { lowest); }\end{array}$ & Absolute & Percentage \\
\hline (1) & (2) & (3) & (4) & $\begin{array}{c}(5)= \\
(2)-(3)\end{array}$ & $(6)=\frac{(2)-(3)}{(3)} * 100 \%$ \\
\hline \multicolumn{6}{|l|}{ Area and population } \\
\hline Area $(\mathrm{km} 2)$ & 95266.8 & 330966.9 & 2 & -235700.10 & -71.22 \\
\hline $\begin{array}{l}\text { Average population } \\
\text { (thousands persons) }\end{array}$ & 11667.5 & 90728.9 & 5 & -79061.40 & -87.14 \\
\hline $\begin{array}{l}\text { Rural population } \\
\text { (thousands persons) }\end{array}$ & 9595 & 60693.5 & 2 & -51098.50 & -84.19 \\
\hline $\begin{array}{c}\text { Share of rural population } \\
(\%)\end{array}$ & 82.24 & 66.90 & 2 & 15.34 & 22.93 \\
\hline $\begin{array}{l}\text { Population density } \\
\text { (people } / \mathrm{km} 2)\end{array}$ & 122 & 274 & 5 & -152.00 & -55.47 \\
\hline $\begin{array}{l}\text { Percentage of literate } \\
\text { population at } 15 \text { years of } \\
\text { age and above }(\%)\end{array}$ & 89 & 94.7 & 6 & -5.70 & -6.02 \\
\hline \multicolumn{6}{|l|}{ Farming activities } \\
\hline $\begin{array}{c}\text { Production of cereals per } \\
\text { capita }(\mathrm{kg})\end{array}$ & 447.9 & 552.9 & 2 & -105.00 & -18.99 \\
\hline Yield of paddy (Quinta/ha) & 48.4 & 57.6 & 5 & -9.20 & -15.97 \\
\hline \multicolumn{6}{|l|}{ Income and poverty } \\
\hline $\begin{array}{l}\text { Monthly income per capita } \\
\qquad(1000 \mathrm{VND})\end{array}$ & 1613 & 2640 & 6 & -1027.00 & -38.90 \\
\hline $\begin{array}{l}\text { Month expenditure per } \\
\text { capita (1000 VND) }\end{array}$ & 1537 & 1888 & 6 & -351.00 & -18.59 \\
\hline $\begin{array}{l}\text { Poverty rate }(\% \text { of } \\
\text { households })\end{array}$ & 18.4 & 8.4 & 1 & 10.00 & 119.05 \\
\hline
\end{tabular}

Note. Poverty rate in 2014 by the government's poverty lines: VND 605 thousand per capita per month for the rural area and VND 750 thousand per capita per month for the urban area.

$1000 V N D \approx \$ 0.045$

Source: (GSO, 2014) 
Farming in the region is characterized by a particularly small scale. Crop diversification is a common characteristic of farm households. A variety of other crops such as starchy crops (maize, potatoes, cassava), vegetables and industrial crops (soybeans, peanuts), fruit, and tea are cultivated to meet household consumption needs and for sale. Rice, a crucial crop for food security, is mostly grown to meet household subsistence demand. Fruits and vegetables are also grown in household gardens. Industrial crops, on the other hand, are planted purely for sale.

With respect to livestock production, a variety of pigs, cattle, buffalo, chickens, and ducks are kept as the main species of livestock. Households rear multiple types of livestock including cow, buffalo, horse, pigs and chickens Pigs are the most common species kept by the majority of households. The main manure source for pig production can be used for crop production. In spite of the fact that pigs are raised to meet market demand for pork, pig rearing is characterized by its small scale. Poultry including chicken and duck are also main sources of food for household consumption and market sale. These species with a shorter life span are considered to be liquid assets for households. Keeping livestock depends on the availability of resources such as labor, animal feed, supplementary feeds from crop production, and especially capital.

\subsection{Method}

\subsubsection{Conceptual Framework}

This section presents the conceptual framework of the study. Accordingly, household capital, comprised of human, financial, physical and social capital, is the main determinant of household likelihood (Bhandari, 2013). Those forms of capital are also assumed to influence household credit accessibility. In return, access to credit is assumed to change the resources and activities of farm households in a positive way, which achieves better household outcomes. Credit might lead to a change in household behavior to use household capital to obtain greater income.

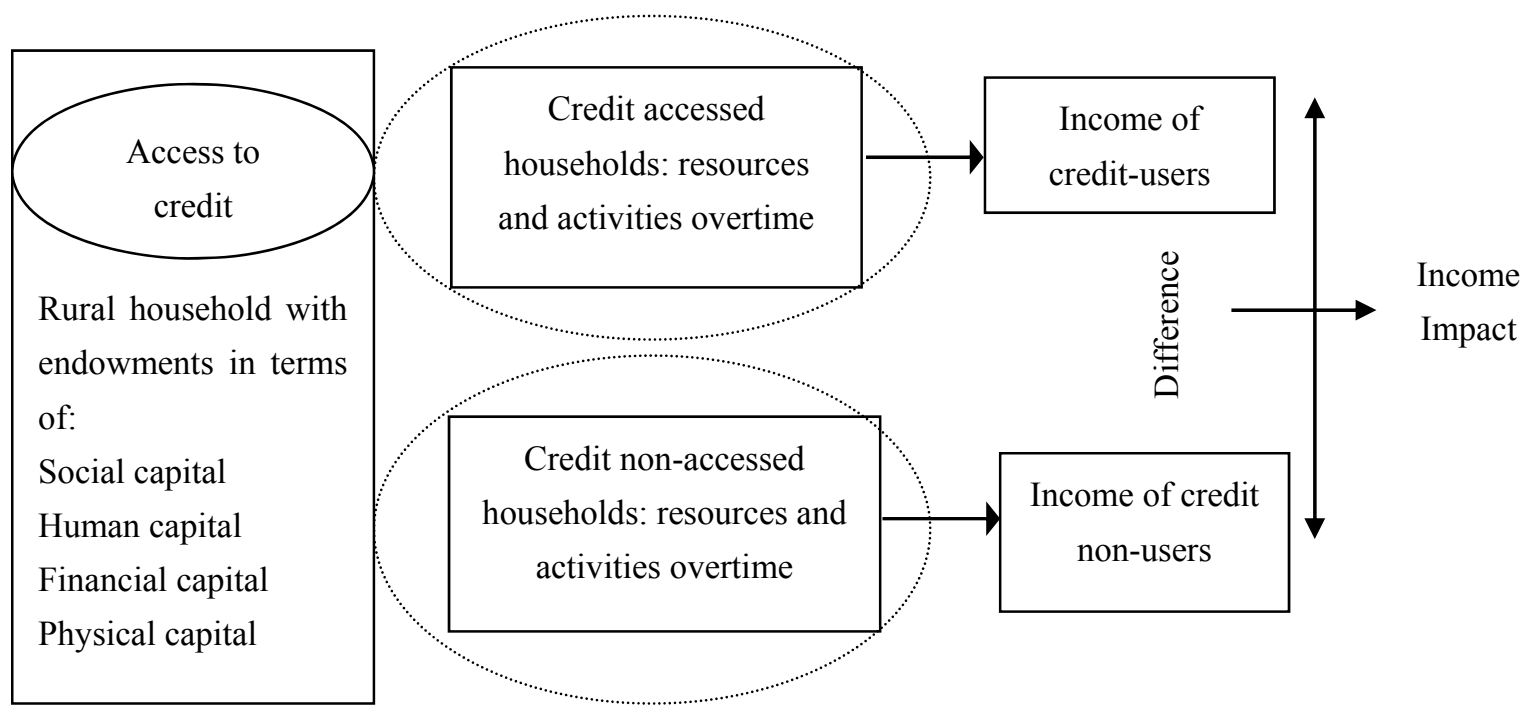

Figure 3. The conceptual framework of the study

Source: Adapted and modified from Hulme (2000)

Numerous studies have shown that credit helps farmers adopt new technology and improve nutrition and education of children (Jacoby \& Skoufias, 1997; Morduch, 1999; Pitt \& Khandker, 1998). Access to credit thoroughly increases household willingness to invest in higher value crops and livestock. Credit is significant for farmers to buy necessary inputs such as fertilizer, seed, crop varieties, pesticides, and animal feed to improve farming productivity (Zeller et al., 1998). In addition, credit is a precondition to adopting agricultural extension services. All of the studies reviewed here suggest a type of impact studies, which is based on investment direction.

The choice of methods used in this study depends very much on the observational data type from the household survey. One methodological concern of this study is that potential selection bias might emerge because participants and non-participants in credit schemes are selected with different outcomes and characteristics. 
Therefore, selection bias can be due to differences in the distributions of characteristics between credit recipients and credit non-recipients groups (or comparison groups). The selection of a comparison group which is not representative of the population can create control selection bias. Outcomes of both households with and without credit access might have already occurred at the time households are selected for study inclusion. In order to address the problem of sample selection bias, this study employs a Heckman Selection Model to analyze determinants of credit access. In addition, the study uses Propensity Score Matching (PSM) which can reduce selection bias by equating both groups of households with and without credit access based on many known characteristics and provides an alternative method for estimating income impact of credit when access to credit is not random. The random selection of surveyed households make two those analytical techniques, which will be discussed in the next section less prone to selection bias.

\subsubsection{Heckman Selection Model}

The choice of the Heckman Selection Model to solve the bias problem has been demonstrated by a report by Heckman (1979). The first step in this model was to analyze the factors affecting the household decision to use credit by applying the probit model. After estimating this model, the Mill ratios were computed. The second step used to identify determinants of credit amount involved the inclusion of the Mill ratios into the following loan equation to adjust for sample selection bias.

$$
Y_{i}=\beta X_{i}+\varepsilon_{i}
$$

In Formula 1, $\mathrm{Y}_{\mathrm{i}}$ is the loan amount and observed only for households who received loans. $\mathrm{X}_{\mathrm{i}}$ represents observed household characteristics and $\varepsilon_{\mathrm{i}}$ is an error term. The Heckman selection model also uses the following assumptions:

$$
(\varepsilon, u) \sim N(0,0, \sigma 2 \varepsilon, \sigma 2 u, \rho \varepsilon u)
$$

Both error terms are normally distributed with a mean of 0 , variances as indicated and the error terms are correlated where $\rho \varepsilon u$ indicates the correlation coefficient; $(\varepsilon, \mathrm{u})$ is independent of $\mathrm{X}$ and $\mathrm{Z}$; The expected loan size may be written as follows:

$$
E\left(Y_{i} / T_{i}=1\right)=E\left(L_{i} / T_{i}>0\right)=E\left(Y_{i} / U_{i}>-\gamma Z_{i}\right)=\beta X_{i}+E\left(\varepsilon_{i} / u_{i}>-\gamma Z_{i}\right)
$$

In terms of (3), $\mathrm{T}_{\mathrm{i}}=1$ represents households with credit access and $E\left(Y_{i} / T_{i}=1\right)$ is the expected loan size of those households. Also in the equation, the problem comes from $\left(\varepsilon_{i} / u_{i}>-\gamma Z_{i}\right)$. The error term $\mathrm{u}$ is restricted to be above a certain value. Those households that do not satisfy this restriction are excluded from the regression. This becomes a problem because of the assumption in (16) that the error terms are correlated where $\rho \varepsilon u$ indicates the correlation coefficient. Heckman's first insight in his 1979 econometric paper was that this can be approached as an omitted variables problem, where $\left(\varepsilon_{i} / u_{i}>-\gamma Z_{i}\right)$ is the 'omitted variable' in (3). An estimate of the omitted variable would solve this problem and hence solve the problem of selection bias. Specifically we can model the omitted variable by:

$$
E\left[\left(\varepsilon_{i} / u_{i}\right)>-Z_{i} \gamma\right]=\rho \varepsilon u \sigma \varepsilon \lambda_{i}\left(-Z_{i} \gamma\right)=\beta \lambda \lambda_{i}\left(-Z_{i} \gamma\right)
$$

In this formula, $\lambda_{i}\left(-Z_{i} \gamma\right)$ is 'just' the inverse Mill's ratio evaluated at the indicated value and $\beta \lambda$ is an unknown parameter $(=\rho \varepsilon u \sigma \varepsilon)$. The inverse Mill's ratio needs to be calculated and added to the estimation of equation (1).

\subsubsection{Propensity Score Matching}

Many previous studies have utilized regressions to measure impact. However, the bias and sensitivity of functional forms that occurs from using the simple regression methods has been demonstrated in reports by Imbens and Rubin (2015) and Blundell and Dias (2009). The Propensity Score Matching is particularly useful in offering an effective way of comparing the outcomes between groups with similar characteristics (Huber et al., 2013).

The key assumption of PSM is that credit recipients and non-recipients with similar characteristics should also have the same income. In theory, a pair of comparable households should be quite similar in terms of their characteristics, except for credit access. The matching approach aims to separate the credit impact by making two household groups comparable. The welfare impact is denoted by the Average Treatment Effects on the Treated (ATT). In empirical estimations, each credit recipient $i$ is matched with non-recipient $j$ and their outcome $\mathrm{Y}_{0}$ is weighted by $\mathrm{w}(\mathrm{i}, \mathrm{j})$. ATT is calculated as follows: 


$$
A T T=\frac{1}{n_{1}} \sum_{i \in(D=1)}\left[y_{1, i}-\sum_{j} w(i, j) y_{0, j}\right]
$$

Where:

$\mathrm{n}_{1}$ is the number of matched recipients;

$\mathrm{Y}_{1 \mathrm{i}}$ is the outcome for the matched recipient $\mathrm{i}$;

$Y_{0 j}$ is the outcome for the matched non-recipient $j$; and $w(i, j)$ are weights.

In the PSM, a variety of matching approaches including the nearest-neighbor matching, radius matching, Kernel matching and stratification matching have been used to measure the effects of credit. The idea of nearest-neighbor matching is that each treated unit is matched with the nearest neighbor of a control unit. Based on this algorithm, the individual non-recipient is selected as a matching partner for a recipient that is closest in terms of propensity score. The second approach is radius matching, which uses all observations of a control group within one radius such as 0.001 . In other words, each recipient is matched with a non-recipient that falls within a specified radius. A smaller radius can improve the quality of matching because matched non-recipients have closer scores to recipients (Caliendo \& Kopeinig, 2008). In Kernel matching, all observations for control groups are used to match with each treated unit. Closer control units are imposed by higher weights and further units are incorporated by lower weights (Imai et al., 2010). In this study, each credit recipient is matched with several credit non-recipients, with weights inversely proportionate to the distance between accessed and non-accessed households. The purpose of stratification matching is to compare the outcomes within intervals or blocks of propensity scores. It requires that the average propensity scores of recipients and non-recipients are not statistically different. Becker and Ichino (2002) revealed that the covariates are balanced and the assignment to treatment can be considered random by construction in each block. Each has its advantages and drawbacks. Their joint consideration, however, offers a way to assess the robustness of the estimates (Becker \& Ichino, 2002). The distribution for the ATT estimator is additionally constructed using a bootstrapping approach in order to increase the reliability of estimation measures.

\section{Results}

\subsection{Descriptive Statistics}

\subsubsection{Household Endowments}

This analysis excludes 245 recipients of subsidized credit, 6 recipients of Pepple's Credit Fund and 80 recipients of informal credit in order to separate the income impact of Agribank credit. Regarding total household income, a total of 114 household observations of outliers were removed to smooth data for better impact estimations. To help distinguish income differences between credit recipients and non-recipients, households are classified into two categories according to their access to credit. The differences in household endowments between the two groups are of interest because they might explain the variations in credit accessibility. Wilcoxon rank sum and Pearson Chi squared tests were used to analyze the differences between credit recipients and non-recipients (see Table 2 for further details).

Table 2. Difference in household endowments between households with access to credit and those without

\begin{tabular}{lcccc}
\hline \multicolumn{1}{c}{ Variables } & $\begin{array}{c}\text { All sample } \\
(\mathrm{n}=899)\end{array}$ & $\begin{array}{c}\text { Recipient } \\
\text { households } \\
(\mathrm{n}=54)\end{array}$ & $\begin{array}{c}\text { Non-recipient } \\
\text { households } \\
(\mathrm{n}=845)\end{array}$ & $\begin{array}{c}\text { Wilcoxon } \\
\text { rank-sum, } \\
\text { Pearson } \\
\text { chi2 tests }\end{array}$ \\
\hline $\begin{array}{l}\text { Number of household visits to agricultural extension } \\
\text { in the last 12 months (number) }\end{array}$ & 1.788654 & 3 & 1.711243 & $2.667^{* * *}$ \\
Family size (persons) & $(1.748001)$ & $(3.670381)$ & $(1.518271)$ & \\
& 4.860957 & 4.092593 & 4.910059 & $-3.121^{* * *}$ \\
Ethnicity of household heads (1= ethnic minorities) & $(2.139255)$ & $(2.030601)$ & $(2.137779)$ & \\
The distance of the household to the commune center & $(.7185762$ & .4074074 & .7384615 & $27.5078^{* * *}$ \\
$(\mathrm{~km})$ & $(5.9745945)$ & $(.4959656)$ & $(.4397328)$ & \\
\hline
\end{tabular}




\begin{tabular}{|c|c|c|c|c|}
\hline Age household heads (years) & $\begin{array}{c}48.40378 \\
(14.19952)\end{array}$ & $\begin{array}{c}46.51852 \\
(10.66424)\end{array}$ & $\begin{array}{c}48.52426 \\
(14.39247)\end{array}$ & 0.569 \\
\hline $\begin{array}{l}\text { General education of household heads (years in } \\
\text { school) }\end{array}$ & $\begin{array}{c}9.01891 \\
(3.729238)\end{array}$ & $\begin{array}{c}8.703704 \\
(2.311821)\end{array}$ & $\begin{array}{c}9.039053 \\
(3.801925)\end{array}$ & -1.315 \\
\hline $\begin{array}{l}\text { Share of nonfarm-nonwage income in total } \\
\text { household income }(\%)\end{array}$ & $\begin{array}{l}.8105998 \\
(.3596798)\end{array}$ & $\begin{array}{l}.8515776 \\
(.2941646)\end{array}$ & $\begin{array}{l}.8079811 \\
(.3634536)\end{array}$ & 0.299 \\
\hline Households exposure to any types of shocks $(1=$ Yes $)$ & $\begin{array}{l}.6985539 \\
(.4591414)\end{array}$ & $\begin{array}{l}.6666667 \\
(.475831)\end{array}$ & $\begin{array}{l}.7005917 \\
(.4582701)\end{array}$ & 0.2774 \\
\hline Economic losses due to shocks (VND 1000) & $\begin{array}{c}3943.91 \\
(8584.857)\end{array}$ & $\begin{array}{c}1893.5 \\
(2918.038)\end{array}$ & $\begin{array}{c}4074.942 \\
(8808.761)\end{array}$ & -1.129 \\
\hline Total value of savings (VND 1000) & $\begin{array}{c}7814.56 \\
(27227.26)\end{array}$ & $\begin{array}{c}7054.259 \\
(20481.96)\end{array}$ & $\begin{array}{c}7863.147 \\
(27611.07)\end{array}$ & -1.462 \\
\hline Total value of household asset (VND 1000) & $\begin{array}{c}11810.55 \\
(12771.99)\end{array}$ & $\begin{array}{c}12985.19 \\
(19643.12)\end{array}$ & $\begin{array}{c}11735.49 \\
(12216.25)\end{array}$ & 0.612 \\
\hline
\end{tabular}

Note. absolute value of standard deviation in parentheses

** Significant at $5 \% ; * * *$ Significant at $1 \%$

Source: own calculation

As Table 2 shows, credit recipients are different from non-recipients in a number of aspects. Recipients were shown to have better access to extension services. Various forms of extension services include field conferences, direct visits between extension workers and households, as well as study tours have been designed to encourage exchanges of knowledge and experience. Farmers received extension information relating to the adaptation of new varieties, pest and disease control as well as fertilizer application. On average, family size and the proportion of ethnic minorities are shown to be larger in non-recipients. In Vietnam, despite the overall impressive achievements, ethnic minorities have experienced lower rates of poverty reduction than the general population. The minority community accounted for only $14.5 \%$ of the total population, but they make up $50 \%$ of the poor (World Bank, 2009). Compared to non-recipients, recipients live closer to the communal center and market, creating household opportunities for social communication and transaction cost reduction. Table 2 further reveals that there is no significant difference between households with access to credit and those without in terms of the remaining variables such as age and education of household heads, the share of nonfarm income in total household income, shocks in terms of both incidence and severity, savings and household asset.

\subsubsection{Loan Characteristics}

An average loan volume of 64.84 million VND equivalent to $93 \%$ of total income is significantly high. On average, the monthly interest rate charged by the agricultural bank is around $1.36 \%$. The average duration of the loans from inception was greater than one and a half years at the date of the survey. Another loan characteristic is that collateral security is required for $88 \%$ of loans in the form of land titles. Monthly payment is the most common mode of repayment for $85 \%$ of loans. The proper utilization in the appropriate fields of loans can yield more benefits for farmers. Among credit recipients, $34 \%$ used loans for animal husbandry and $12 \%$ for crops. In addition, $40 \%$ of recipients used it to finance nonfarm investment, which is expected to obtain higher economic returns than farming activities. A remaining $14 \%$ share of recipients used loans for other purposes including home consumption, heath expenses, education expenses, housing improvement and so on.

\subsection{Regression Results}

\subsubsection{Determinants of Household Participation in Credit Schemes}

Before proceeding to examine the effects of credit, it is necessary to analyze determinants of credit access. Heinrich et al. (2010) suggested that "including irrelevant variables (that do not influence participation in the intervention) should be avoided so that they do not worsen the common support problem or unnecessarily increase the variance of the estimates". In this current study, irrelevant variables refer to the statistically insignificant variables in the probit regresion results. For this reason, Table 3 only reports the significant variables of the probit estimation of the PSM. The dependent variable equals one if the household takes out an Agribank loan and otherwise equals zero. The percentage of correct predictions is very high, around $94.7 \%$, indicating the appropriateness of the model in analyzing the determinants of credit access by households. 
Table 3. Probit estimation of accessing Agribank credit

\begin{tabular}{lcccc}
\hline Explanatory variables & Coefficients & $\begin{array}{c}\text { Standard } \\
\text { errors }\end{array}$ & Z-value & $\begin{array}{c}\text { Marginal effect } \\
\text { dy/dx }\end{array}$ \\
\hline Constant & -1.280984 & 0.1118263 & $-11.46^{* * *}$ & - \\
Log (Number of contacts with agricultural & 0.3244127 & 0.0855604 & $3.79^{* * *}$ & 0.0292657 \\
extension in the last 12 months and vice versa) & & & & \\
Ethnicity of household heads & -0.5608311 & 0.1190376 & $-4.71^{* * *}$ & -0.0505934 \\
(1= ethnic minorities) & -0.0330054 & 0.013654 & $-2.42^{* *}$ & -0.0029775 \\
Log (Total value of savings) & 1338 & & & \\
Number of observations & 42.53 & & & \\
LR chi2(3) & 0.0000 & & & \\
Prob > chi2 & 0.0766 & & & \\
Pseudo R2 & $94.69 \%$ & & & \\
Correctly classified (\%) & & & & \\
\hline
\end{tabular}

Note: ${ }^{* * *}$ significant at $1 \%,{ }^{* *}$ significant at $5 \%,{ }^{*}$ significant at $10 \%$

Source: own calculation

Results show that access to commercial loans is strongly influenced by the extent to which recipients participate in agricultural extension programs. The coefficient of the number of visits by extension services is positive and significant at $1 \%$ statistical significance. A one percent increase in the number of extension visits raises the conditional probability of accessing preferential credit by $0.029 \%$, given the other variables are held constant. This finding suggests once again the role of extension services in improving household access to information as well as credit. This result is in agreement with the findings of Hoang et al. (2006) who showed that the efficient delivery of extension services improves social networks and benefits from development.

Ethnic minorities are less likely to access Agribank credit. This is evident in the ethnicity variable, which has a negative sign and significant coefficient at a $1 \%$ level of statistical significance. Differences in endowments between ethnic minorities and the Kinh majority have also influenced credit access. Switching from ethnic minority to ethnic majority households results in a 5.05\% increase in the probability of accessing Agribank credit. In general, it seems that the minority community still lags behind in terms of receiving commercial credit. These results are in line with those recorded by Dufhues and Buchenrieder (2005), which showed that ethnic minorities have a significantly higher chance of being access-constrained than the ethnic majority in the $\mathrm{Ba} \mathrm{Be}$ and Yen Chau district of the Northern Mountains of Vietnam. Furthermore, the Kinh majority holds crucial positions in the local administration, consisting of various commercial bank branches. Commercial lenders restrict credit access to the poor and ethnic minorities due to the fact that those households have rising default rates.

Another factor influencing access to Agribank credit is amount of savings. This variable is negatively associated with access to commercial loans at 5\% statistical significance. A one percent increase in amount of savings would yield a $0.0029 \%$ decrease in the conditional probability of accessing Agribank credit. One possible explanation for this result is that savings in kind are held by rural households which have low access to financial intermediaries (Newman et al., 2008). The liquidation of those savings serve as funding for household investment.

\subsubsection{Determinants of Credit Volumes}

Table 4 presents the determinants of the extent of household access to Agribank credit, as measured by loan size. As the Table shows, the selection bias problem is not present in this credit model because the inverse Mill's ratio (lamda) is not statistically significant at $5 \%$. The model accounts for $26.76 \%$ of the total variability in Agribank loan volumes. Results indicate that physical assets have a substantial effect on volumes of commercial credit. A household owning more valuable assets can obtain a larger amount of commercial credit. An increase of one percent in asset value results in a $0.29 \%$ increase in loan size. In the formal commercial credit sector, assets are the principal indicator of the wealth level of a household. Assets yield more opportunities for investment and therefore increased loan volumes from commercial sources. It seems possible that the Agribank focuses on granting larger volumes of credit to those who are better off. For this reason, it is not surprising that a higher value of assets significantly affects the extent of credit access. This finding is in line with that in the previous analysis of credit outreach, revealing that Agribank credit favors clients in the better-off and richest groups. 
Coefficients of other explanatory variables, such as share of nonfarm income, family size and ethnicity, have expected signs but are not statistically significant.

Table 4. Determinants of Agribank loan volumes

\begin{tabular}{lccc}
\hline Explanatory variables & Coefficients & Standard errors & Z-value \\
\hline Constant & 7.464712 & 0.7996736 & $9.33^{* * *}$ \\
Log (Total value of household asset) & 0.2929013 & 0.0583079 & $5.02^{* * *}$ \\
Log (Share of nonfarm-nonwage income in total household & 0.1061928 & 0.096358 & 1.10 \\
income) & -0.1904658 & 0.1750815 & -1.09 \\
Log (Family size) & -0.2954798 & 0.2169112 & -1.36 \\
Ethnicity of household heads (1= ethnic minorities) & 899 & & \\
Number of observations & 845 & & \\
Censored observations & 54 & \\
Uncensored observations & 32.85 & & \\
Wald chi2(4) & 0.0000 & & \\
Prob $>$ chi2 & & & \\
Mills & 0.3655152 & 0.3482042 & \\
$\quad$ Lambda & 0.50792 & & \\
$\quad$ Rho & 0.71962886 & & \\
Sigma & 6.12 & & \\
F(5, 49$)$ & 0.0001 & & \\
Prob $>$ F & 26.76 & & \\
Adjusted R-squared (\%) & &
\end{tabular}

Note. Dependent variable is Log (credit amount)

${ }^{* * *}$ significant at $1 \%,{ }^{* *}$ significant at $5 \%,{ }^{*}$ significant at $10 \%$

Source: own calculation

\subsection{Income Impact of Credit}

\subsubsection{Before Matching}

Table 5. Income difference before matching, in thousands VND, 2012

\begin{tabular}{lcccc}
\hline Income & $\begin{array}{c}\text { All sample } \\
(\mathrm{n}=899)\end{array}$ & $\begin{array}{c}\text { Recipients } \\
(\mathrm{n}=54)\end{array}$ & $\begin{array}{c}\text { Non-recipients } \\
(\mathrm{n}=845)\end{array}$ & $\begin{array}{c}\text { Two-sample Wilcoxon } \\
\text { rank-sum (Mann-Whitney) test }\end{array}$ \\
\hline Total income & 39316.96 & 46936.39 & 38830.03 & $3.027^{* * *}$ \\
& $(26062.16)$ & $(23350.75)$ & $(26163)$ & \\
Per capita income & 9663.639 & 14512.57 & 9353.767 & $4.127^{* * *}$ \\
& $(7846.22)$ & $(10784.48)$ & $(7523.169)$ & $-4.354^{* * *}$ \\
Total farm income & 18448.02 & 11082.13 & 18918.74 & $4.570^{* * *}$ \\
& $(14595.88)$ & $(12969.44)$ & $(14574.44)$ & 1.460 \\
Total nonfarm income & 13946.85 & 24315.3 & 13284.25 & \\
& $(24324.34)$ & $(23198.49)$ & $(24257.29)$ & $2.752^{* * *}$ \\
Nonfarm - nonwage income & 3387.148 & 8457.519 & 3063.124 & \\
Wage income & $(16879.29)$ & $(20507.63)$ & $(16582.51)$ &
\end{tabular}

Note. absolute value of standard deviation in parentheses

$1000 V N D \approx \$ 0.045$

$* * *$ significant at $1 \%$ 
As shown in Table 5, accessed households tend to perform better than non-accessed on income generating, except in terms of farm income. Credit recipients reported significantly greater income, per capita income, and non-farm income than non-recipients. However, no significant difference in farm income could be found between those two groups. It does not clearly explain the income difference, but it might be related to the variations in the quality and quantity of household resources allocated for economic activities. The results might also be attributed to the type of different credit access; therefore, matching is essential for inferring the causal welfare impact of credit.

\subsubsection{After Matching}

The impact of credit was calculated by averaging the differences in outcome between each treated group and the matched control group. Impact estimations were estimated using both normal matching and bootstrap matching with 5000 replications of sampling with replacements of the examination sample to adjust for bias caused by sampling errors. The treatment variable denotes participation in the credit schemes of the Agribank. As mentioned in the previous section, an outcome variable includes total income and its components. The mean of bias decreased from $49.5 \%$ to $8.5 \%$ and covariates become insignificant after matching. Using the propensity scores estimated in the probit model, credit recipients were matched with similar non-recipients to appraise the impact of credit on different components of income. Coefficients were approximated using different matching algorithms to validate that results were not driven by the choice of a certain matching approach. The matching algorithms used are nearest-neighbor, radius with a caliper of 0.001 , Kernel using a normal density, and stratification. Furthermore, standard errors were also estimated using bootstrapping in brackets. The estimation results and the robustness check are also shown in Table 6.

As Table 6 shows, commercial loans have significantly positive effects on total income, per capita income, total nonfarm income and nonfarm nonwage income. Those coefficients are not dependent on different matching approaches, indicating the robustness of the results. Total household income illustrates this point clearly, as those households with access to commercial credit obtained from 5888.39 thousand VND to 14372.11 thousand VND $(14.56 \%$ to $43.78 \%)$ more in total income than those without. Estimates of per capita income range from $12.09 \%$ to $51.83 \%$. However, the analysis further indicated that there are no effects of commercial credit on total farm income. The coefficient of farm income is not statistically significant and changes its statistical significance according to the estimation methods.

Table 6. Income impact of commercial credit by the Agribank, in thousands VND, 2012

\begin{tabular}{cccccc}
\hline \multirow{2}{*}{ Categories of income } & \multicolumn{4}{c}{ Matching algorithms } \\
& & Nearest neighbor & Radius (0.001) & Kernel & Stratification \\
\hline \multirow{3}{*}{ Total } & ATT & 5888.39 & 14372.11 & 7395.29 & 6959.64 \\
income & Percentage change (\%) & 14.56 & 43.78 & 18.74 & 17.48 \\
& Standard error & 3439.97 & 3767.49 & 3322.46 & 3441.15 \\
& t-statistic & $1.89^{*}$ & $3.70^{* * *}$ & $2.25^{* *}$ & $2.07^{* *}$ \\
& ATT & 1529.65 & 4975.06 & 4224.55 & 3338.20 \\
Per capita income & Percentage change (\%) & 12.09 & 51.83 & 40.82 & 29.87 \\
& Standard error & 1636.91 & 1741.04 & 1514.97 & 1596.75 \\
& t-statistic & 1.14 & $2.67^{* * *}$ & $2.75^{* * *}$ & $2.09^{* *}$ \\
Farm & ATT & -3229.47 & -3730.58 & -5731.09 & -4155.67 \\
income & Percentage change (\%) & -22.94 & -26.46 & -34.48 & -27.53 \\
& Standard error & 2045.81 & 2004.69 & 1866.00 & 1928.43 \\
& t-statistic & -1.46 & $-1.87^{*}$ & $-2.97^{* * *}$ & $-2.08^{* *}$ \\
& ATT & 7635.20 & 13120.34 & 9066.76 & 7378.80 \\
Nonfarm income & Percentage change (\%) & 46.18 & 111.60 & 59.46 & 43.64 \\
& Standard error & 3752.84 & 3950.75 & 3430.10 & 3635.27 \\
& t-statistic & $2.07^{* *}$ & $3.30^{* * *}$ & $2.64^{* * *}$ & $2.04^{* *}$ \\
\cline { 3 - 6 } Nonfarm & ATT & 5279.73 & 5468.40 & 5052.11 & 5014.26 \\
\hline
\end{tabular}




\begin{tabular}{cccccc}
\hline Nonwage & Percentage change (\%) & 160.43 & 180.92 & 147.79 & 145.34 \\
& Standard error & 3074.99 & 3138.53 & 2846.73 & 2798.24 \\
& t-statistics & $1.68^{*}$ & $1.78^{*}$ & $1.77^{*}$ & $1.79^{*}$ \\
& ATT & 2254.77 & 7547.87 & 4019.79 & 2446.59 \\
\multirow{2}{*}{ Wage income } & Percentage change (\%) & 17.03 & 86.42 & 33.98 & 18.18 \\
& Standard error & 3243.21 & 2964.13 & 2647.41 & 2827.84 \\
Number of treatment (households) & 0.81 & $2.50^{* *}$ & 1.52 & 0.85 \\
Number of control (households) & 54 & 53 & 54 & 54 \\
\hline
\end{tabular}

Note. 1000 VND $\approx \$ 0.045$

* Significant at $10 \% ; * *$ significant at $5 \% ; * * *$ significant at $1 \%$

ATT: Average Treatment on Treated Effect is bias corrected by bootstrapping method

Source: own calculation

Consistent with expectations, the results of this section show a substantial increase in the total nonfarm income of Agribank credit recipients. This positive impact of credit on nonfarm income is explained by the fact that nonfarm activities are essential for rural livelihood, as farming activities are risky. These results are in line with those of Stampini and Davis (2009), who found that nonfarm income is a complementary source of investment in seeds, services, hired labor, and livestock inputs. Nonfarm income relaxes credit constraints to farming. In another study conducted by Haggblade et al. (2010), it was shown that the non-farm economy is a potential pathway to reducing poverty for the rural poor. An association exists between the poor's access to financial capital and their participation in nonfarm activities. Facilitating the nonfarm economy can help the poor to improve their access to credit and other resources. Imai et al. (2015) also concluded that access to rural non-farm employment significantly reduces poverty and vulnerability for households in both Vietnam and India. Diversification of household activities in the non-farm sector would reduce risks.

The strong evidence of the significant contribution of commercial credit to household income, especially non-farm income can be linked to a number of factors. The Agribank performs as a profit-oriented commercial bank, sustaining the development of rural areas. The bank focuses its lending on relatively richer households. Recipients of commercial loans appear to use credit for financing nonfarm activities, which could be more profitable and prone to fewer risks from bad weather conditions. During the last two decades, the bank has clearly expanded its share of total rural credit and this process is in line with the rapid development of the national economy.

The Agribank model in Vietnam is quite similar to the cases of the Bank for Agriculture and Agricultural Cooperatives (BAAC) in Thailand, the Bank Rakyat Indonesia (BRI) in Indonesia, and the Land Bank in the Philippines, which have demonstrated their success in providing financial services to a majority of rural inhabitants. Overall, these cases support the view that the expansion of credit should be in conjunction with the development of small enterprises and farms to decline transaction costs.

On the basis of market principles, understanding and serving the actual demand of borrowers have shown effectiveness in supplying credit services over time. Turning now to the experience of the Agribank, it has made loan disbursement plans suited to the cash flow of borrowers. Furthermore, greater credit volumes of the bank may be associated with the larger investment and yields. An empirical work was undertaken by Saldias and von Cramon-Taubadel (2012) suggesting that increased loan volume has boosted efficiency of crop farms in Chile. Collateral security requirement could have played a vital role in bringing about incentives for borrowers to invest in high-yielding activities. Giné (2011) suggested that enforcement of private contracts and the registration of property seem to be much more effective in improving credit access for the formal sector in Thailand. Also, credit recipients appear to use credit for financing nonfarm activities, which could be more profitable and prone to fewer risks. This reason is consistent with findings by Simtowe et al. (2006), which indicated that credit is useful only for households with access to remunerative businesses and investment opportunities. Another factor for these effects is that the bank targets the less-poor clients as compared to the general population. Based on the national poverty line, the share of credit recipients who are poor represents $18 \%$ compared to $25 \%$ of non-recipients. The Agribank tend to provide credit to wealthier households, which have collateral and demand 
larger loans to reduce the transaction costs per unit of loan. In addition, location and distance from the market center is another factor allowing credit recipients to reduce transaction costs. In this study, the average travel distance to the market center is 2.47 compared to 3.85 kilometers in the case of non-recipients. Khoi et al. (2013) found that convenient access to village roads improves household access to formal loans in the Mekong River Delta of Vietnam. Better road connection can reduce transaction costs of accessing credit and markets. Khandker et al. (1995) noted that infrastructure and market connection determine the yields, farming productivity, and credit repayment by clients of Grameen Bank in Bangladesh. Similarly, Paxton (1996) asserted that better access to markets improves household credit repayment.

\section{Conclusions}

The provision of credit to rural households is not meaningful if it does not improve their welfare. Effects of credit on poverty reduction, therefore, have become a central issue in the rural credit system. The continuous supply of credit depends on the profitability of recipients using loans. However, published data on the effects of the credit of the Agribank, the leading rural credit provider in Vietnam, is currently scarce. A primary concern of this study is to assess the income impact of Agribank credit on households in disadvantaged rural areas of Vietnam.

The study has found that provision of credit to rural households increased their total income, per capita income, and total nonfarm income. An implication of this study is the possibility that the Agribank credit has partly contributed to the poverty reduction of Vietnam in the last two decades.

The findings of this study have a number of important implications for future practice. This information can be used to develop targeted interventions aimed at fulfilling household demand for credit in the country. There is, therefore, a definite need for the expansion of this credit source. However, poor households are still excluded from accessing the Agribank credit. Therefore, continued efforts are needed to make those loans more accessible to the poorer households. This study also emphasizes that the development of small enterprises and farms is in partnership with the development of rural credit. Considering the needs of farmers, the bank has succeeded in providing rural households with financial services over time.

The success in mobilizing savings in cash plays an important role in providing households with a greater loan volume. The historical development of rural credit has showed that the provision of savings services is vital to rural areas and farmers. In return, savings are the main source of financing lending activities. In most cases, a larger loan volume would be sufficient for households to expand production and efficiency.

Access to additional resources can have a profound and positive impact on credit recipients. More access to extension services and risk coping measures should therefore be made available to households to increase farming productivity. Credit is an important financial resource for farming inputs such as seed, fertilizer and animal feed. More importantly, extension enhances farming practices, which help farmers use credit more effectively. Another way of improving risk coping strategies could be through extension services. For example, extension to enhance veterinary hygiene and protection against epidemics might reduce risks and economic losses and enhance the impact of credit.

Another important practical implication is that the Agribank credit schemes tend to be more adaptable to the farming seasonality and the cash flow of households. The provision of timely credit is crucial for households to purchase agricultural inputs and invest in production equipment. The lending procedure of the agricultural bank, which is primarily based on the principles of the rural credit market, seems to satisfy household demand. These findings also support the view that the expansion of credit should be in conjunction with the development of small enterprises and farms to reduce transaction costs.

\section{Acknowledgements}

The authors wish to deeply thank the Vietnamese Central Institute for Economic Management (CIEM), Vietnamese Institute of Policy and Strategies for Agriculture and Rural Development (IPSARD) for providing the data. We also thank Mr. Danner McCulloh for English correction of the text. Appreciation also to the editor and an anonymous reviewer for their excellent comments that helped us to improve the article.

\section{References}

Agribank. (2014). Annual Report 2014. Ha Noi: Vietnam Bank for Agriculture and Rural Development.

Becker, S. O., \& Ichino, A. (2002). Estimation of average treatment effects based on propensity scores. The Stata Journal, 2(24), 358-377.

Bhandari, P. B. (2013). Rural livelihood change? Household capital, community resources and livelihood 
transition. Journal of Rural Studies, 32, 126-136. http://dx.doi.org/10.1016/j.jrurstud.2013.05.001

Blundell, R., \& Dias, M. C. (2009). Alternative Approaches to Evaluation in Empirical Microeconomics. Journal of Human Resources, 44(3), 565-640.

Caliendo, M., \& Kopeinig, S. (2008). Some practical guidance for the implementation of propensity score matching. Journal of economic surveys, 22(1), 31-72.

Dufhues, T., \& Buchenrieder, G. (2005). Outreach of credit institutes and households' access constraints to formal credit in Northern Vietnam.

Dufhues, T., Dung, P. T. M., Hanh, H. T., \& Buchenrieder, G. (2001). Fuzzy information policy of the Vietnam Bank for the Poor in lending to and targeting of the poor in Northern Vietnam: Grauer.

Giné, X. (2011). Access to capital in rural Thailand: An estimated model of formal vs. informal credit. Journal of Development Economics, 96(1), 16-29. http://dx.doi.org/10.1016/j.jdeveco.2010.07.001

GSO, General Statistics Office of Vietnam. (2012). Statistical Handbook of Vietnam. Ha Noi: Statistical Publishing House.

GSO, General Statistics Office of Vietnam. (2014). Statistical Handbook of Vietnam. Ha Noi: Statistical Publishing House.

Haggblade, S., Hazell, P., \& Reardon, T. (2010). The Rural Non-farm Economy: Prospects for Growth and Poverty Reduction. World Development, 38(10), 1429-1441. http://dx.doi.org/10.1016/j.worlddev.2009.06. 008

Hazarika, G., \& Alwang, J. (2003). Access to credit, plot size and cost inefficiency among smallholder tobacco cultivators in Malawi. Agricultural Economics, 29(1), 99-109. http://dx.doi.org/10.1016/S0169-5150(03) 00020-3

Heckman, J. J. (1979). Sample selection bias as a specification error. Econometrica: Journal of the econometric society, 153-161.

Heinrich, C., Maffioli, A., \& Vazquez, G. (2010). A primer for applying propensity-score matching: Inter-American Development Bank.

Hoang, L. A., Castella, J.-C., \& Novosad, P. (2006). Social networks and information access: Implications for agricultural extension in a rice farming community in northern Vietnam. Agriculture and Human Values, 23(4), 513-527.

Huber, M., Lechner, M., \& Wunsch, C. (2013). The performance of estimators based on the propensity score. Journal of Econometrics, 175(1), 1-21. http://dx.doi.org/10.1016/j.jeconom.2012.11.006

Hulme, D. (2000). Impact Assessment Methodologies for Microfinance: Theory, Experience and Better Practice. World Development, 28(1), 79-98. http://dx.doi.org/10.1016/S0305-750X(99)00119-9

Imai, K. S., Arun, T., \& Annim, S. K. (2010). Microfinance and Household Poverty Reduction: New Evidence from India. World Development, 38(12), 1760-1774. http://dx.doi.org/10.1016/j.worlddev.2010.04.006

Imai, K. S., Gaiha, R., \& Thapa, G. (2015). Does non-farm sector employment reduce rural poverty and vulnerability? Evidence from Vietnam and India. Journal of Asian Economics, 36, 47-61. http://dx.doi.org/10.1016/j.asieco.2015.01.001

Imbens, G. W., \& Rubin, D. B. (2015). Causal Inference in Statistics, Social, and Biomedical Sciences: An Introduction. Cambridge University Press.

Jacoby, H. G., \& Skoufias, E. (1997). Risk, financial markets, and human capital in a developing country. The Review of Economic Studies, 64(3), 311-335.

Khandker, S. R., Khalily, M. A. B., \& Khan, Z. H. (1995). Grameen Bank: performance and sustainability (Vol. 306). World Bank Publications.

Khoi, P. D., Gan, C., Nartea, G. V., \& Cohen, D. A. (2013). Formal and informal rural credit in the Mekong River Delta of Vietnam: Interaction and accessibility. Journal of Asian Economics, 26(0), 1-13. http://dx.doi.org/10.1016/j.asieco.2013.02.003

Morduch, J. (1999). The role of subsidies in microfinance: evidence from the Grameen Bank. Journal of Development Economics, 60(1), 229-248. http://dx.doi.org/10.1016/S0304-3878(99)00042-5

Newman, C., Tarp, F., Van den Broeck, K., Quang, C. T., \& Khai, L. D. (2008). Household savings in Vietnam: 
insights from a 2006 rural household survey. Vietnam Economic Management Review, 3(1), 34-40.

Paxton, J. (1996). Determinants of successful group loan repayment: an application to Burkina Faso. The Ohio State University.

Pitt, M. M., \& Khandker, S. R. (1998). The impact of group-based credit programs on poor households in Bangladesh: Does the gender of participants matter? Journal of political economy, 106(5), 958-996.

Saldias, R., \& von Cramon-Taubadel, S. (2012). Access to credit and the determinants of technical inefficiency among specialized small farmers in Chile. Diskussionspapiere, Department für Agrarökonomie und Rurale Entwicklung.

Seibel, H. D. (1992). The making of a market economy: monetary reform, economic transformation and rural finance in Vietnam (Vol. 19). Breitenbach.

Seibel, H. D. (2003). Taking stock. Small Enterprise Development, 14(2), 10-12.

Simtowe, F., Zeller, M., \& Phiri, A. (2006). Determinants of Moral Hazard in Microfinance: Empirical Evidence from Joint Liability Lending Programs in Malawi. African Review of Money Finance and Banking, 5-38.

Stampini, M., \& Davis, B. (2009). Does nonagricultural labor relax farmers' credit constraints? Evidence from longitudinal data for Vietnam. Agricultural Economics, 40(2), 177-188.

Van Brabant, J. M. (1990). Reforming a socialist developing country-the case of Vietnam. Economics of Planning, 23(3), 209-229.

World Bank, W. B. (2009). Country Social Analysis Vol. 9976. Ethnicity and Development in Vietnam: Summary Report (pp. 78).

Zeller, M., Diagne, A., \& Mataya, C. (1998). Market access by smallholder farmers in Malawi: Implications for technology adoption, agricultural productivity and crop income. Agricultural Economics, 19(1), 219-229.

\section{Copyrights}

Copyright for this article is retained by the author(s), with first publication rights granted to the journal.

This is an open-access article distributed under the terms and conditions of the Creative Commons Attribution license (http://creativecommons.org/licenses/by/3.0/) 